\title{
KARAKTERISTIK KASIH KRISTIANI MENURUT 1 KORINTUS 13
}

\author{
Dr. Dyulius Thomas Bilo, M.Th.. \\ Sekolah Tinggi Teologi Injili Arastamar (SETIA) Jakarta, \\ greatshine@sttsetia.ac.id
}

\begin{abstract}
Abstrak
Allah adalah kasih. Allah mewujudkan kasih-Nya akan dunia melalui pengutusan anak-Nya yang tunggal Yesus Kristus. Dalam inkarnasi-Nya Yesus mewujudkan kasihNya akan orang-orang berdosa melalui pengorban-Nya di atas kayu Salib. Orangorang Kristen pada umumnya hendaknya menunjukkan kasihnya kepada Allah dan sesamanya dengan meneladani kasih Allah. Demikian pula harapan kepada orangorang percaya di Korintus hendaknya mampu mewujudkan kasih Allah dalam kehidupan mereka dengan mengasihi sesamanya. Namun melalui nasihat Paulus diketahui bahwa mereka lebih cenderung menonjolkan soal karunia-karunia rohani dibanding menjalankan kasih kristiani. Dalam 1 Korintus 13 Paulus menegaskan apakah karakteristik kasih kristiani yang mesti dilakukan oleh orang-orang percaya di Korintus. Tujuan dari tulisan ini adalah menjelaskan apakah karakteristik kasih kristiani menurut 1 Korintus 13.
\end{abstract}

\section{Kata Kunci: Karakteristik, Kasih, Kristiani, Korintus}

\section{A. Pendahuluan}

Bagian ini merupakan pasal yang paling indah di seluruh Perjanjian Baru. Menurut tafsiran Ende, bagian ini disebut "Madah Tjinta-kasih". Dan memang, dalam memaparkan keagungan tjinta-kasih, jaitu tjinta kepada Allah jang berwudjud pula dalam tjinta-kasih kepada sesama manusia. Paulus demikian terharu, sehingga bahasanja mendjelma berungkapan indah-indah dan berirama mendjadi suatu sjair sedjati berbentuk bebas.

Menurut Pfitzner bahwa "ini tak pelak lagi adalah yang paling indah dalam surat-surat Paulus-sebagian orang mungkin mengatakan, dalam seluruh Perjanjian Baru, bahkan di dalam seluruh Alkitab. Meskipun bukan puisi dalam pengertian yang sempit, ayat-ayat ini dengan susunannya yang berirama dan ungkapannya yang jelas, mempunyai kualitas lirik. Ada yang mengatakan bahwa "nyanyian" ini sebelumnya disusun oleh Paulus, dan disisipkan antara 12:31 dan 14:1." Bagi Paulus, bagian ini disebut "most excellent way" is the way is love. Adolf Harnack menyebut pasal ini "The greatest, strongest, deepest thing Paul ever wrote".

Jika diperhatikan penyisipan "nyanyian" kasih Paulus ini di antara pasal 12:31 yang berbunyi "Jadi berusahalah untuk memperoleh karunia-karunia yang paling utama. Dan aku menunjukkan kepadamu jalan yang lebih utama lagi. " dan 14:1 berbunyi demikian "Kejarlah kasih itu dan usahakanlah dirimu memperoleh karuniakarunia Roh, terutama karunia untuk bernubuat." Paulus mempunyai alasan kuat sebagai komentar yang tajam dan kritis tentang kondisi-kondisi di Korintus, kondisi 
perlaku pembacanya yang tidak mengenal kasih. Dimana terjadi pertikaian antar kelompok $(1: 11,12)$, semangat untuk membalas dendam kepada orang lain persis seperti yang telah dilakukannya kepada mereka (6:1-8), ketidakpedulian mereka yang tidak bertenggang rasa terhadap mereka yang imannya lebih lemah (8:7-13; 10:23-30), dan sikap masa bodoh yang tidak mengenal malu terhadap anggotaanggota yang lebih miskin pada perjamuan-perjamuan kasih dan perjamuan Tuhan (11:17-22), mereka menyangkal buah-buah Roh sementara membanggakan karuniakarunia-Nya.

Itulah sebabnya Rasul Paulus memulai dengan suatu pernyataan keras bahwa seseorang mungkin terpanggil melayani, mempunyai banyak karunia rohani, dan sering mengadakan tanda-tanda mujizat, tetapi jika tanpa kasih, semuanya itu tidak ada gunanya. Maksud lain bahwa sebenarnya dari semua karunia yang diberikan Allah, karunia yang paling utama dan hakiki adalah karunia kasih. Kasih adalah karunia yang paling utama (1 Kor. 13:1-3).

Dari penjelasan Rasul Paulus dalam pasal 13 ini terindikasi ada 16 karakteristik kasih yang dapat memungkinkan seseorang dapat melayani dengan baik dan efektif, menerbarkan karunia-karunia rohani dan dipercayakan Tuhan mengadakan tandatanda mujizat serta dapat mengalami kehidupan bahagia dan berkelimpahan.

\section{B. PEMBAHASAN}

\section{Jalan yang Lebih Utama}

Sebelum lebih jauh menggambarkan karakteristik kasih Kristen, dalam pasal 12:31 diungkap kalimat terakhir "Aku menunjukkan kepadamu jalan yang utama lagi." Apakah yang dimaksudkan dengan kalimat ini?, Pfitzner menjelaskan:

Meskipun teks Yunaninya agak tidak jelas, tidak mungkin ayat ini memaksudkan bahwa Paulus mempertentangkan kasih dengan karunia-karunia rohani, atau mengajukan kasih sebagai pengganti dari semuanya itu; itu tentunya sebuah perbandingan yang sia-sia. Seperti iman dan kasih (ay.13), kasih adalah miliki semua orang percaya, sementara tidak semua orang memiliki karunia-karunia yang sama $(12: 29,30)$. Paulus mempertentangkan sikap membanggakan diri karena mereka memiliki sebuah karunia untuk diri sendiri, namun digunakan tanpa kasih, dengan penggunaan karunia-karunia itu dengan kerendahan hati di dalam pelayanan yang penuh kasih kepada orang lain... istilah "jalan" ini bukan jalan menuju kasih, melainkan jalan dalam kasih. Dalam Perjanjian Lama, tindakan etis seringkali digambarkan sebagai berjalan disebuah jalan tertentu (Mzm. 1:2; Yes. 59:8). Mengikuti tradisi Perjanjian Lama dan Yahudi ini, Paulus seringkali berbicara tentang perilaku Kristen sebagai berjalan di sebuah jalan (Rm.6:4; 8:4; 2 Kor. 5:7; Gal.5:16; Ef. 2:2, 10; 5:8,15; Kol.3:7). Sebelumnya dalam surat ini, Paulus telah memperingatkan para pembacanya tentang "jalan-jalan yang telah diajarkanya kepada mereka (14:17)...Pengajarannya jelas mencakup petunjuk tentang jalan kasih (Rm.14:15; Ef. 5:2) yang berbicara tentang "hidup atau berjalan, RSV) di dalam kasih" sebagai hakikat etika Kristen. Jadi Paulus sudah menduga bahwa orang Korintus tahu sesuatu tentang jalan dalam kasih, barangkali ayat 31 berarti: "Aku ingin memperlihatkan kepada kamu dengan lebih jelas lagi jalan (kasih) itu". 
Pemikiran yang sama diungkapkan oleh Matthew Henry, bahwa di sini, Rasul Paulus menunjukkan jalan lebih utama. Jalan yang ia maksudkan adalah jalan kasih (Inggris: charity), yang di tempat lain umumnya kata ini diterjemahkan sebagai kasih dari kata agape. Bukan kasih yang biasa kita gunakan dan yang dipahami oleh sebagian besar orang sebagai pemberian amal sedekah, melainkan kasih dalam arti sepenuhnya dan yang paling luas, kasih yang sejati kepada Allah dan sesama manusia, kebaikan hati kepada sesama saudara Kristen, yang tumbuh dari ibadah yang tulus dan sungguh kepada Allah. Dasar yang hidup dari semua kewajiban dan ketaatan itulah yang dimaksudkan dan dibicarakan oleh Rasul Paulus, lebih utama daripada semua karunia lainnya. Bahkan tanpa kasih ini, karunia-karunia yang paling mulia sekalipun tidak akan ada artinya, tidak ada nilainya bagi kita dan tidak berharga di hadapan Allah.

\section{Pentingnya Kasih Kristen}

Dalam ayat 1-3 dituliskan "Sekalipun aku dapat berkata-kata dengan semua bahasa manusia dan bahasa malaikat, tetapi jika aku tidak mempunyai kasih, aku sama dengan gong yang berkumandang dan canang yang gemerincing. Sekalipun aku mempunyai karunia untuk bernubuat dan aku mengetahui segala rahasia dan memiliki seluruh pengetahuan; dan sekalipun aku memiliki iman yang sempurna untuk memindahkan gunung, tetapi jika aku tidak mempunyai kasih, aku sama sekali tidak berguna. Dan sekalipun aku membagi-bagikan segala sesuatu yang ada padaku, bahkan menyerahkan tubuhku untuk dibakar, tetapi jika aku tidak mempunyai kasih, sedikitpun tidak ada faedahnya bagiku."

Istilah "sekalipun" atau "satu kali pun" dalam KBBI merupakan kata penghubungan untuk menandai perlawanan makna. Kata ini sama dengan sebelas kata lainnya yaitu "adapun", "andaipun", "ataupun”, "bagaimanapun", "biarpun", "kalaupun", "maupun", "walaupun", "sungguhpun”, "meskipun”, dan "kendatipun". Tetapi perlu diketahui bahwa partikel "pun" tidak hanya berarti penolakan tetapi mengandung arti "juga" yang merupakan adverbia (kata keterangan (dalam bahasa Latin: ad, "untuk", dan verbum, "kata", artinya suatu kelas kata yang memberikan keterangan kepada kata lain seperti verb (kata kerja), adjektiva (kata sifat), yang bukan nomina (kata benda).

Paulus dalam bagian ini, menekankan betapa pentingnya kasih dalam kehidupan orang percaya sehingga hal lain yang pernah, sedang dan akan dibuat oleh seseorang akan tidak berarti apabila tidak mempunyai kasih. Dalam 1 Korintus 13, Paulus menegaskan enama hal menjadi penanda pentingnya kasih dalam kehidupan orang Kristen, yaitu: Sekalipun aku dapat berkata-kata dengan semua bahasa manusia dan bahasa malaikat, tetapi jika aku tidak mempunyai kasih, aku sama dengan gong yang berkumandang dan canang yang gemerincing. Sekalipun aku mempunyai karunia untuk bernubuat tetapi jika aku tidak mempunyai kasih, aku sama sekali tidak berguna. Sekalipun aku mengetahui segala rahasia dan memiliki seluruh pengetahuan, tetapi jika aku tidak mempunyai kasih, aku sama sekali tidak berguna. Sekalipun aku memiliki iman yang sempurna untuk memindahkan gunung, tetapi jika aku tidak mempunyai kasih, aku sama sekali tidak berguna. Dan sekalipun aku membagibagikan segala sesuatu yang ada padaku, tetapi jika aku tidak mempunyai kasih, sedikitpun tidak ada faedahnya bagiku." Sekalipun aku menyerahkan tubuhku untuk 
dibakar, tetapi jika aku tidak mempunyai kasih, sedikitpun tidak ada faedahnya bagiku." Keenam hal tersebut dapat dijelaskan sebagai berikut:

1. Sekalipun aku dapat berkata-kata dengan semua bahasa manusia dan bahasa malaikat, tetapi jika aku tidak mempunyai kasih, aku sama dengan gong yang berkumandang dan canang yang gemerincing.

Sekalipun orang dapat berkata-kata dengan menggunakan semua bahasa di atas muka bumi ini dengan tepat, anggun dan fasih, bahkan juga dapat berkata-kata seperti malaikat, tetapi jika tidak disertai kasiym semua kata-kata itu, hanyalah kegaduhan yang kosong belaka, bunyi yang tidak serasi dan tidak berguna, yang tidak membawa keuntungan dan sukacita. Pfitzner menegaskan bahwa seseorang boleh berkata-kata dengan semua bahasa manusia, dengan menggunakan bahasa-bahasa manusia yang normal, atau bahasa malaikan, memuji Allah dengan kata-kata yang bernada sorgawi dan tidak dengan sendirinya dipahami atau diucapkan oleh manusia $(4: 2 ; 2$ Kor.12:4); tetapi semua bahasa yang mulia di dalam pujian kepada Allah itu menampilkan suara dari gong yang berkumandang dan canang yang gemerincing bila mereka yang berbicara itu tidak mempunyai kasih. Gong dan canang bukan hanya alat-alat musik dalam ibadah bait Allah di dalam Perjanjian Lama dan dalam ibadah Yahudi belakangan (Mzm.150:5), mereka pun memainkan peranan penting dalam ibadah-ibadah kafir yang ekstatik (penuh sukacita). Di sini Paulus tidak menentang bahasa roh, tetapi memohon agar semuanya itu digunakan dengan kasih. Sudah tentu benar ia maksudkan kasih untuk sesama Kristen yang harus dibangun imannya, tetapi memang benar pula bahwa "petunjuk" liturgis dengan nyanyian-nyanyian yang indahm paduan suaram dan musik organ semuanya adalah suara-suara yang hampa kecuali bila dinaikkan dalam pujian kepada Allah dengan penuh kasih.

2. Sekalipun aku mempunyai karunia untuk bernubuat tetapi jika aku tidak mempunyai kasih, aku sama sekali tidak berguna.

Nubuat dapat dikatakan sebagai prediksi tentang apa yang akan terjadi di kemudian hari pada sesuatu atau pada seseorang yang sifatnya mengandung unsur baik dan buruk dan berkaitan dengan hal-hal yang rohani. Itulah sebabnya orang-orang yang memiliki karunia nubuat dan terbukti, maka disebut sebagai orang-orang yang unggul, hebat dan rohani. Namun menurut Paulus orang-orang seperti ini pun kalau tidak mempunyai kasih tidak ada faedahnya.

Seseorang bahkan mungkin mempunyai karunia yang lebih unggul (14:5) berupa kuasa bernubuat, dimana nubuat mempradugakan hikmat dan pengetahuan tentang rahasia-rahasia Allah di dalam Kristus $(4: 1 ; 12: 8,10$; Rm.16:25; Ef. 3:3-5; Kol.2:2,3). Tetapi itu pun tidak ada artinya tanpa kasih. Sekalipun orang mengerti dengan jelas berbagai nubuat dan gambaran dari masa Perjanjian Lama, tetapi kalau tidak memiliki kasih orang itu sama sekali tidak ada apa-apanya.

3. Sekalipun aku mengetahui segala rahasia dan memiliki seluruh pengetahuan, tetapi jika aku tidak mempunyai kasih, aku sama sekali tidak berguna. 
Perhatikanlah memiliki kecerdasan yang cemerlang dan mendalam tidak akan ada gunanya tanpa disertai oleh hati yang penuh kebaikan dan kemurahan, bukanlah pengetahuan yang hebat yang dihargai Allah, melainkan ibadah dan kasih yang sejati dan dalam. Pfitzner memaparkan meskipun ia begitu berbakat, semua pembicaraan manusia, persepsinya tentang hikmat ilahi, dan pengetahuannya yang mendalam mungkin tidak mengesankan Allah yang dapat melihat lebih dalam daripada kata-kata dan tindakan-tindakan luar. Tanpa kasih, orang seperti itu, mungkin tidak jauh lebih baik daripada seorang kafir yang menawar-nawarkan mode keagamaan yang paling baru.

4. Sekalipun aku memiliki iman yang sempurna untuk memindahkan gunung, tetapi jika aku tidak mempunyai kasih, aku sama sekali tidak berguna.

Seseorang mungkin mempunyai iman yang sempurna (12:9) sehingga mampu untuk memindahkan gunung-sebuah hiperbola atau ungkapan yang membesar-besarkan yang disengaja. Paulus mungkin mengacu pada pengajaran Yesus (Mat.17:20; 21:21); tetapi ada ungkapan peribahasa Yahudi: "mencabik-cabik gunung" yang artinya sama saja dengan melakukan sesuatu yang tidak mungkin. Bahkan pembuktian yang jelas tentang iman kepada Allah yang menghancurkan bumi tidak bisa menyangkal kebenaran ini yaitu jika aku tidak mempunyai kasih, aku sama sekali tidak berguna, sekurang-kurangnya di mata Allah yang adalah hakim terakhir itu $(4: 4,5)$.

Henry menjelaskan bahwa walaupun hal ini menunjukkan suatu iman yang menakjubkan, iman mujizat, atau iman yang memampukan orang melakukan mujizat: Sekalipun aku memiliki iman yang sempurna (suatu iman yang tertinggi tingkatanya) untuk memindahkan gunung (atau berkata kepada gunung itu, beranjaklah dan tercampaklah ke dalam laut dan hal itu terjadi (Mrk.11:23), tetapi jika aku tidak mempunyai kasih, aku sama sekali tidak berguna. Iman yang mampu melakukan mujizat yang paling mengherankan, dimana tidak ada sesuatu yang mustahil, sama sekali tidak berguna tanpa kasih. Memindahkan gunung merupakan pencapaian besar dalam pandangan manusia, tetapi dalam pandangan Allah, setitik kasih jauh lebih berharga dari pada semua iman yang hebat di dunia seperti ini. Orang-orang yang melakukan banyak mujizat dalam nama Kristus pun bahkan tidak diakui-Nya dan diusir dari hadapan-Nya seperti para pekerja yang berbuat kejahatan (Mat.7:22-23). Iman yang menyelamatkan selalu berkaitan dengan kasih, tapi iman mujizat mungkin saja ada tanpa kasih.

5. Dan sekalipun aku membagi-bagikan segala sesuatu yang ada padaku, tetapi jika aku tidak mempunyai kasih, sedikitpun tidak ada faedahnya bagiku."

Tindakan kasih yang tampak dari luar: Membagikah segala sesuatu yang ada padanya untuk member makan orang miskin (ay.3) Sekalipun ada orang yang melakukan sesuatu seperti ini, jika ia tidak memiliki kasih, ia sama sekali tidak berguna. Mungkin saja ada orang yang suka menghamburhamburkan harta tanpa disertai hati yang lapang dan penuh kasih. Tindakan memberikan sedekah yang tampak dari luar dapat saja berasal dari niat yang jahat. Lagak pamer kebaikan yang sia-sia atau menyombongkan jasa kebaikan, dapat membuat orang menghamburkan harta tanpa disertai dengan kasih sejati kepada Allah atau manusia. Perbuatan baik kita kepada orang lain sama 
sekali tidak aka nada gunanya bagi kita, jika tidak dilakukan dengan baik, yaitu berdasarkan asas pengabdian dan kasih kepada Allah serta niat baik kepada sesama manusia. Perhatikanlah, jika kita menghilangkan kasih dari kehidupan keagamaan kita, maka pelayanan kita yang paling mahal sekalipun tidak aka nada gunanya bagi kita, sementara kita tidak memberikan hati kita kepada Allah, maka perbuatan itu sama sekali tidak berguna. Yesus mempunyai katakata tajam untuk mereka yang menyombongkan amal mereka di depan umum (Mat. 6:2). Bahkan sekalipun aku membagi-bagikan segala sesuatu yang ada padaku, sedikit demi sedikit untuk member makan kepada mereka yang lapar, dan tidak mempunyai kasih, sedikitpun tidak ada faedahnya bagiku-bahkan bila orang miskin itu mendapat keuntungan dari kemurahan hatiku, seperti yang seharusnya terjadi. Bahkan pengorbanan yang paling tinggi pun tidak ada artinya tanpa kasih.

6. Sekalipun aku menyerahkan tubuhku untuk dibakar, tetapi jika aku tidak mempunyai kasih, sedikitpun tidak ada faedahnya bagiku.

Dalam naskah kuno berbunyi "agar aku mendapat kemuliaan dan bukan untuk dibakar." Maksud Paulus, bahkan pengurbanan diri dapat mempunyai tujuan yang egois, dan untuk mendapat pujian dari manusia dan hadiah dari Allah. Paulus sedang membayangkan entah teladan para syuhada Yahudi yang dengan rela menyerahkan hidupnya (bahkan dengan dibakar sampai mati (Dan.3:19, 20; 2 Makabe 7:5; Makabe 6:26; 7:12) dan atau dengan membakar diri untuk menolak dunia ini dan segala harapannya. Perhatikanlah, penderitaan yang paling memilukan, pengorbanan yang paling mahal, sama sekali tidak akan mengundang perkenanan Allah, jika kita tidak mengasihi saudara-saudara seiman kita. Walaupun kita menyerahkan tubuh kita untuk dibakar, hal itu sama sekali tidak berguna. Semuanya ini menekankan pendapat Paulus, "lakukanlah segala pekerjaanmu dalam kasih" (1 Kor. 16:14).

\section{Karakteristik Kasih Kristiani}

Selanjutnya dalam ayat 4-7 yang berbunyi "Kasih itu sabar; kasih itu murah hati; ia tidak cemburu. Ia tidak memegahkan diri dan tidak sombong. Ia tidak melakukan yang tidak sopan dan tidak mencari keuntungan diri sendiri. Ia tidak pemarah dan tidak menyimpan kesalahan orang lain. Ia tidak bersukacita karena ketidakadilan, tetapi karena kebenaran. Ia menutupi segala sesuatu, percaya segala sesuatu, mengharapkan segala sesuatu, sabar menanggung segala sesuatu." Bagi penulis inilah karakteristik kasih Kristiani yang dipaparkan oleh Paulus. Keenambelas karakteristik kasih kristiani dapat didaftarkan singkat sebagai berikut:

1. Kasih itu sabar

2. kasih itu murah hati

3. Kasih itu tidak cemburu

4. Kasih itu tidak memegahkan diri

5. Kasih itu tidak sombong

6. Kasih itu tidak melakukan yang tidak sopan

7. Kasih itu tidak mencari keuntungan diri sendiri 


\author{
8. Kasih itu tidak pemarah \\ 9. Kasih itu tidak menyimpan kesalahan orang lain \\ 10. Kasih itu tidak bersukacita karena ketidakadilan \\ 11. Kasih itu bersukacita karena kebenaran \\ 12. Kasih menutupi segala sesuatu \\ 13. Kasih itu percaya segala sesuatu \\ 14. Kasih itu mengharapkan segala sesuatu \\ 15. Kasih itu sabar menanggung segala sesuatu \\ 16. Kasih itu tidak berkesudahan
}

Dari keenambelas karakteristik kasih kristiani tersebut, dapat dibagi dalam dua bagian, dimana bagian pertama terdapat tujuh hal yang berupa pernyataan bersifat positif yaitu kasih itu sabar; kasih itu murah hati; kasih itu bersukacita karena kebenaran, kasih menutupi segala sesuatu, kasih itu percaya segala sesuatu, kasih itu mengharapkan segala sesuatu, kasih itu sabar menanggung segala sesuatu. Dan bagian yang kedua terdapatsembilan pernyataan yang bersifat negatif yaitu kasih itu tidak cemburu, kasih itu tidak memegahkan diri, kasih itu tidak sombong, kasih itu tidak melakukan yang tidak sopan, kasih itu tidak mencari keuntungan diri sendiri, kasih itu tidak pemarah, kasih itu tidak menyimpan kesalahan orang lain, kasih itu tidak bersukacita karena ketidakadilan, dan kasih itu tidak berkesudahan.

Artinya ketujuh hal yang bersifat positif itu harus diusahakan, ditingkatkan dan dipertahankan. Seumur hidupkan kita berupaya untuk menjalankan sifat kasih tersebut. Sementara kesembilan hal yang bersifat negatif tersebut harus ditinggalkan, dilepaskan, dan dihilangkan/dilenyapkan. Sebaliknya seumur hidup kita bertarung dan berjuang untuk meninggalkan, menanggalkan, melawan, dan melepaskan hal-hal yang bersifat negatif tersebut. Selanjutnya keenambelas karakteristik kasih kristiani ini akan diuraikan secara singkat sebagai berikut

\title{
1. Kasih itu Sabar
}

Dalam bahasa Yunani "makrothumein" kata yang digunakan dalam Perjanjian Baru yang menunjukkan kesabaran terhadap orang atau manusia dan bukan kesabaran terhadap keadaan atau kondisi. Chrysostomus berkata bahwa kata ini dipakai untuk seseorang yang diperlakukan secara tidak adil dan yang dengan kekuasaannya dapat menuntut balas dengan mudah, namun sekalipun begitu ia tidak mau melakukannya.

Istilah "sabar" sama artinya dengan tahan menderita. Ia menghadapi dengan tabah kesalahan dan penghinaan orang lain, bahkan juga orang-orang yang malas, tawar hati, dan lemah (1 Tes. 5:14). Dengan sabar menanggung kejahatan dari orangorang yang merugikan, tidak berkobar-kobar dengan kemarahan dan pembalasan.

Kata ini mengambarkan seseorang yang tidak begitu cepat marah dan dipakai untuk Allah sendiri dalam hubungannya dengan manusia. Dalam hubungannya dengan manusia, antara sesama manusia, betapa pun keras kepala, betapa pun tidak berbelas kasihan, betapa pun jahatnya dan menyakitkan, kita harus tetap berlatih kesabaran sebagaimana Allah melakukannya ketika berhadapan dengan manusia. Kesabaran seperti ini bukanlah suatu kelemahan melainkan justru suatu kekuatan.

Henry menjelaskan bahwa kasih itu sabar-makrothymei yaitu kasih yang sanggup menanggung perbuatan jahat, luka-luka dan hasutan, tanpa dipenuhi oleh kebencian, kejengkelan, atau balas dendam. Kasih membuat pikiran menjadi tabah, 
memberikan kekuatan untuk mengalahkan nafsu amarah serta melengkapinya dengan kesabaran yang benar. Kasih seperti itu membangun sikap lebih baik menunggu dan mengharapkan terjadinya perubahan dari saudara seiman daripada menumpahkan rasa benci atas tingkah lakunya. Kasih seperti itu dapat menampung banyak kelalaian dan kegagalan dari orang yang dikasihim dan menunggu sampai lama untuk melihat pengaruh yang baik dari kesabaran seperti itu kepada orang itu.

\section{Kasih itu Murah Hati}

Kasih itu murah hati-chrēsteuetai yaitu kasih seperti itu adalah kasih yang baik hati, melimpah dalam memberi. Kasih itu sopan dan suka membantu. Pengajaran yang lemah lembut ada di bibirnya, hatinya lapang dan tangannya terbuka. Ia selalu siap menunjukkan sikap suka menolong dan berbuat baik. Dia berusaha menjadi orang yang berguna, tidak saja berusaha menangkap kesempatan untuk berbuat baik, tetapi berusaha mencarinya. Inilah sifatnya secara umum. Ia sabar di bawah perbuatan yang tidak adil, serta suka dan cenderung melakukan kebaikan apa saja semampunya.

Origenes menuliskan "berbaik hati kepada semua orang". Jerome menuliskan hal ini sebagai "keramahan" kasih. Begitu banyak orang Kristen yang baik tetapi tidak ramah.

\section{Kasih itu Tidak Cemburu.}

Ada dua jenis kecemburuan. Pertama cemburu terhadap miliki orang lain, kadang hal ini sulit dihindari dalam kehidupan seseorang dan sifat sangat manusiawi. Artinya ia dengan sukacita mengakui kesuksesan dan prestasi orang lain; ia bahkan dapat bersukacita ketika orang lain memperlihatkan bakti bahwa mereka memiliki karuniakarunia "yang lebih tinggi" (1 Kor. 12:16; 31a).

Kedua, kecemburuan karena orang lain sudah memiliki apa-apa yang belum kita miliki. Kecemburuan yang kedua ini lebih berat karena intinya adalah ketidakinginan orang memperoleh dan mendapatkan apa-apa. Ia akan selalu mengagalkan atau mengganjalnya.

Kasih itu tidak bersedih atas keberuntungan orang lain. Juga tidak terhadap karunia-karunia atau sifat-sifat mereka yang baik, serta tidak terhadap kehormatan mereka dan harta benda mereka. Kalau kita mengasihi sesama kita, kita tidak boleh sedikit pun merasa iri atau cemburu terhadap kesejahteraan mereka atau merasa tidak senang dengan keadaan itu. Supaya kita juga dapat berbagi dan turut bersukacita atas semua yang mereka miliki itu. Kebahagiaan dan pengudusan mereka akan menambah kebahagiaan dan pengudusan kita, dan bukannya malah menganggu atau menguranginya. Inilah pengaruh yang tepat dan benar dari kebaikan hati dan perbuatan baik itu. Iri hati merupakan pengaruh yang datang dari niat yang jahat. Kesejahteraan yang kita harapkan bagi orang lain, tidak akan pernah membuat kita bersedih hati. Begitu pula pikiran yang cenderung berbuat baik kepada semua orang tidak akan pernah disertai kejahatan kepada siapa pun.

\section{Kasih itu Tidak Memegahkan Diri}

Kasih sejati tidak menonjolkan diri. Kasih sejati menjauhkan sifat-safat ke "aku" an, egosentris. Selalu merasa menonjol, lebih dari yang lain, dan merasa tanpa "saya" kamu atau lembaga tidak ada artinya, tidak ada "apa2" nya. Kasih tidak bertindak seperti seorang pongah yang menceritakan diri sendiri ketika keberhasilan datang, 
atau apabila seseorang jelas mempunyai sebuah karunia yang tidak dimiliki oleh orang lain.

Dalam bahasa Aram, diterjemahkan sebagai non tumultuatur-tidak membangkitkan keributan dan gangguan. Kasih akan menenangkan nafsu amarah, dan bukan menimbulkannya. Beberapa orang menterjemahkan sebagai non perperà et perversè agit, tidak melakukan tindakan berbahaya secara diam-diam kepada siapa pun juga, tidak berusaha menjerat, menjebak mereka. Juga tidak berusaha membuat orang marah dengan hal-hal yang tidak perlu. Kasih itu tidak bandel, keras kepala dan bertentangan. Beberapa orang memahaminya sebagai tidak berpura-pura dan menjilat-jilat. Kasih tidak menyukai kepura-kepuraan dan perbuatan menjilat.

\section{Kasih itu Tidak Sombong}

Kasih akan selalu mengikis sifat merasa hebat dan lebih dari yang lain. Orangorang hebat yang berhati mulia akan selalu berkata bahwa kesuksessannya itu hasil kerja bersama, hasil tim. Bukan hasil pribadi semata-mata. Kesombongan adalah tanda bahwa seseorang mempunyai penilaian yang palsu tentang dirinya sendiri yang suka membuat perbandingan-perbandingan palsu dan tidak berdasarkan kasih antara dirinya dengan orang lain-sudah tentu, selalu dengan akibat bahwa orang lain "direndahkan". Carey, seorang missionary hebat, ahli bahasa yang memiliki kemampuan menterjemahkan bahasa melayani di India. Seseorang ingin menjatuhkan dia dan berkata bahwa dia adalah pembuat sepatu, tetapi Carey menjawab dengan lembut ia hanyalah seorang tukang sepatu.

Kasih yang tidak sombong, adalah kasih yang tidak mengembungkan oleh kesombongan diri, tidak membesarkan diri atas pencapaian-pencapaiannya. Juga tidak menyombongkan diri dengan kehormatan, kekuasaan dan penghargaan yang bukan menjadi bagiannya. Kasih tidak kasar dan jumawa, suka merendahkan orang lain, atau menginjak-injak mereka, atau memperlakukan mereka dengan menghina dan mengejek. Orang-orang yang hatinya digerakkan oleh dasar kasih persaudaraan yang sejati akan saling mendahului dalam member hormat (Rm. 12:10). Mereka tidak akan pernah mencari puji-pujian yang sia-sia, sebaliknya dengan rendah hati mereka menganggap orang lain lebih utama dari pada mereka (Flp. 2:3). Kasih yang sejati akan membuat kita lebih suka memberikan rasa hormat kepada sesama dan meninggikan diri sendiri, supaya tidak membesar-besarkan diri dan angkuh, Sifatsifat yang tidak baik ini tidak akan pernah tumbuh dari perasaan kasih kepada sesama saudara seiman, juga tidak dari kebajikan yang berlimpah-limpah.

\section{Kasih itu Tidak Melakukan yang Tidak Sopan}

Kasih sejati menuntut kesucian,tanpa cela. Setiap tutur kata dan tindakan selalu menampilkan hal-hal yang baik dan benar. Kepada siapa pun selalu berlaku sopan dan memenuhi standar etika pergaulan. Baik sendiri maupun bersama orang lain, baik dilihat atau tidak dilihat orang lain tetap ia menjaga kesopanannya. Pfitzner menjelaskan kasih tidak melakukan yang tidak sopan, artinya tidak bertindak dengan tidak hormat terhadap orang lain. Bila kasih memang ada di Korintus, yang miskin tidak akan diperlakukan dengan cara yang mempermalukan dan direndahkan pada perjamuan-perjamuan kasih dan perjamuan Tuhan (1 Kor. 11:22), demikian pula tidak aka nada ancaman bahwa seorang pemuda bertindak dengan tidak hormat kepada tunangannya (1 Kor. 7:36). 
Henry menjelaskan kasih itu berhati-hati untuk tidak melanggar batas-batas kesopanan. Istilah ouk aschēmonei-tidak melakukan yang tidak sopan, tidak melakukan yang tidak pantas, tidak melakukan apa pun yang pada umumnya dianggap orang sebagai sesuatu yang hina atau jahat. Kasih itu tidak melakukan sesuatu yang tidak pada tempatnya atau tidak tepat pada waktunya, tetapi memperlakukan semua orang sesuai dengan sederajatnya dan sebagai sesame dengan menaruh rasa hormat dan menghargai orang-orang yang berderajat lebih tinggi, dengan menunjukkan kebaikan hati dan bersikap rendah hati kepada orangorang yang berderajat lebih rendah, serta dengan penuh kesopanan dan kehendak baik kepada semua orang. Kasih itu tidak merusak tatanan, tidak berusaha menyamakan derajat yang akan membuat semua orang berada pada derajat yang sama, tetapi bertujuan untuk tetap menjaga perbedaan yang diadakan Allahg di antara manusia, serta bertindak dengan sopan di dalam kedudukannya sendiri dan mengurus urusannya sendiri, tanpa menyalahgunakannya untuk memperbaiki, mengecam, atau memandang rendah tingkah laku orang lain.

\section{Kasih itu Tidak Mencari Keuntungan Diri Sendiri.}

Ciri-ciri orang Kristen yang penuh kasih adalah bahwa ia selalu mengutamakan kepentingan orang lain, dan bukan berusaha untuk mencari keuntungan diri sendiri (Flp.2:3, 4; Rm. 12:3, 10). Jadi kasih tidak memaksakan kehendaknya sendiri apabila terjadi perdebatan atau tabrakan kepentingan. Kasih tidak mencari keuntungannya sendirim melainkan kebaikan sesame (1 Kor. 10;24, 33). Bahkan bila seseorang memiliki "pengetahuan" dan yakin akan kemerdekaannya untuk bertindak dalam cara tertentu, kesejahteraan sesamaya akan lebih diutamakan (1 Kor. 8:7-13).

Henry berkata kasih merupakan musuh utama bagi sifat mementingkan diri sendiri: Tidak mencari keuntungan diri sendiri, tidak menginginkan dan juga tidak mencari pujian, kehormatan, keuntungan atau kesenangan bagi diri sendiri. Sesungguhnya, pada tingkat tertentu mengasihi diri sendiri merupakan hal wajar bagi semua orang, dan menjadi bagian dari tubuh jasmaninya. Kasih yang wajar kepada diri sendiri dijadikan sebagai ukuran untuk mengasihi orang lain oleh Juruselamat kita, sehingga kasih yang digambarkan di sini adalah kasihilah sesamamu manusia seperti dirimu sendiri. Rasul Paulus tidak bermaksud supaya kasih menghancurkan segala sesuatu yang berkaitan dengan diri sendiri. Ia tidak bermaksud supaya kasih menghancurkan segala sesuatu yang berkaitan dengan diri sendiri. Ia tidak bermaksud supaya orang yang murah hati tidak boleh mempertahankan apa yang menjadi miliknya, dan sama sekali mengabaikan diri sednri berikut semua kepentingannya. Karena itu kasih harus tumbuh dari dasar yang dibentuk di dalam sifat kita. Namun kasih tidak pernah berusaha menyakiti orang lain atau mengabaikan orang lain. Sering kali kasih mengabaikan diri sendiri demi kepentingan orang lain, lebih menyukai kesejahteraan, kepuasaan, dan keuntungan orang lain di atas kepentingan diri sendiri. Kasih selalu lebih menyukai keuntungan bagi orang banyak, masyarakat umum maupun rohani, daripada keuntungan pribadi. Kasih itu tidak akan memajukan, memperluas, kekuasaan, memperkaya, atau menyenangkan diri sendiri, dengan membebani dan mendatangkan kerusakan kepada masyarakat luas. 


\section{Kasih itu Tidak Pemarah}

Istilah "marah" artinya ketidaksenangan yang hebat, dengan keinginan untuk menghukum atau membalas dendam, terhadap apa yang dianggap sebagai ketidakadilan atau sebagai penghinaan. Tidak pemarah-Ou paroxynetai artinya tidak cepat merasa jengkel atau marah. Kasih memperbaiki ketajaman penguasaan diri, mempermanis dan memperlembut pikiran, sehingga tidak cepat berprasangka dan juga tidak langsung melampiaskan hawa nafsu yang kuat. Dimana api kasih terpelihara dengan baik, api amarah tidak mudah menyala dan juga tidak akan berkobar lama. Kasih tidak akan pernah menjadi marah tanpa sebab, dan akan berusaha keras untuk mengendalikan hawa nafsu di dalam batas-batas tepat, sehingga tidak melampaui ukuran yang pantas, baik derajatnya maupun lama berlangsungnya. Amarah tidak akan dapat tinggal di dalam hati sanubari yang berada di bawah pemerintahan kasih. Kita akan menjadi sulit mara kepada orang-orang yang kita kasihi, bahkan akan membuat kita menjadi mudah membuang kekesalan kita dan menjadi rukun kembali. Tidak pemarah sama halnya tidak mudah tersinggung, tidak mudah dibangkitkan amarahnya atau merasa disakiti ketika orang lain memaksakan kehendaknya atau bersikeras bahwa mereka selalu benar.

\section{Kasih itu Tidak Menyimpan Kesalahan Orang Lain.}

Kasih tidak mencatat semua keburukan yang dikatakan atau dilakukan terhadap dirinya. Seseorang yang dipenuhi kasih tidak suka mencatat kegagalan-kegagalan orang lai untuk memuji dirinya sendiri; sukacitanya yang sejati datang dari mencatat perbuatan-perbuatan baik orang lain, dan dalam memujinya. Ia jelas tidak berusaha membalas dendam, seperti yang dilakukan sebagian orang di Korintus, sehingga bahkan menyeret saudaranya yang Kristen ke hadapan hakim kafir (1 Kor. 6:1-6).

Demikian pula kasih tidak menyimpan kebencian, juga tidak memberikan kesempatan bagi pembalasan dendam, begitulah yang dipahami oleh sebagian orang. Kaish tidak cepat marah, juga tidak menyimpang amarah dalam waktu yang lama. Kasih tidak pernah berbuat jahat, juga tidak bermaksud membalas dendam. Kasih tidak berburuk sangka kepada orang-orang lain, ou logizetai to kakon-tidak menyimpan yang jahat, tidak menuduh kejahatan dengan mereka-reka dan sindirin tidak langsung, sementara kebenarannya tidak pasti. Kasih yang sejati tidak cenderung menjadi iri hati dan curiga. Kasih akan menyembunyikan kesalahankesalahan yang muncul dan menutupinya di balik tirai, dan tidak berusaha mencaricari serta menyingkap apa yang tertutup dan tersembunyi. Kasih tidak akan pernah menaruh curiga tanpa bukti, tetapi lebih suka menyamarkannya dan tidak mempercayai bukti yang melawan orang yang diserang. Kasih tidak akan pernah cepat berburuk sangka, dan menyimpulkan pendapat buruk tentang orang lain berdasarkan penampilan belaka, juga tidak akan memberi tempat bagi kecurigaan tanpa bukti, kasih tidak tidak akan memperburuk sesuatu, tetapi berusaha menciptakan sesuatu yang baik walaupun di tengah-tengah keburukan.

\section{Kasih itu tidak bersukacita karena ketidakadilan}

Henry mengatakan bahwa kasih tidak suka melukai atau menyakiti hati siapa saja. Kasih tidak berburuk sangka kepada siapa pun tanpa disertai bukti yang sangat jelas. Kasih tidak mengharapkan sesuatu yang buruk bagi siapa pun, apa lagu melukai atau menyakiti siapa pun, setidaknya tidak akan menjadikan hal ini sebagai sesuatu yang menyenangkan, bersukacita dalam melakukan kejahatan dan kekacauan. Kasih 
juga tidak akan bersukacita atas kesalahan dan kegagalan orang lain, dan bersoraksorak atas mereka, juga tidak merasa bangga atau berniat jahat, sebab hal itu akan menyulut rasa unggul diri atau memuaskan rasa dendam. Dosa-dosa orang lain lebih menjadi suatu kesedihan bagi jiwa yang penuh kasih, dan bukan sebagai bahan gurauan atau kesenangan. Mereka akan menyinggung sebentar dan merasa iba, namun tidak mempertimbangkannya lebih jauh lagi. Bersenang-senang dalam kesengsaraan sesame mahkluk merupaka suatu kebencian tingkat tinggi. Bukankah jatuh dalam dosa merupakan bencana terbesar yang dapat menimpa seseorang? Betapa tidak cocoknya hal itu dengan kasih kekristenan, jika ada yang bersukacita atas kejatuhan semacam itu.

\section{Kasih itu Bersukacita karena Kebenaran}

Suatu ungkapan "melakukan kebenaran" (Yoh. 3:21), kebenaran dapat berarti tindakan yang benar, dan dengan demikian seringkali sejajar dengan ketidakadilan sebagai lawannya (Rm. 1;18; 2:8; 2 Tes. 2:1-2). Henry mengungkapkan hal berkenaan dengan keberhasilan Injil, yang di dalam penekanan Perjanjian Baru umumnya disebut sebagai kebenaran. Bersukacita melihat orang-orang dibentuk untuk memiliki watak yang sesuai dengan Injil dan menjadi baik. Tidak bersukacita atas dosa-dosa mereka, tetapi sangat bersukacita melihat mereka berbuat baik, membuktikan diri mereka sebagai orang yang jujur dan tulus. Kita akan sangat puas ketika melihat kebenaran dan keadilan berkembang menjadi kuat dan berpengaruh di antara manusia, ketika kebenaran menjadi nyata, iman dan kepercayaan bersama dibangun serta melihat kesalehan dan hidup keagamaan bertumbuh subur.

\section{Kasih Menutupi Segala Sesuatu}

Sudah tentu bukan berarti bahwa ia menerima segala sesuatu yang didengarnya tentang orang lain. Istilah panta stegei, diartikan menutupi segala sesuatu. Petrus menegaskan kasih menutupi banyak sekali dosa (1 Pet.4:8). Kecenderungan manusia adalah menyerang dan membeberkan persoalan orang dengan orang lain. Jonathan Lamb mengatakan bahwa kasih akan menuntun seseorang untuk membicarakan persoalannya dengan orangnya bukan dengan orang lain.

Kasih akan menutupi semuaya dibalik tirai, sepanjang hal itu sesuai dengan kewajibannya. Tanpa ada maksud untuk menyebarluaskan atau mengumumkan kesalahan-kesalahan seorang saudara, sampai kebutuhan yang dapat memaksa hal ini keluar dari pikiran yang penuh kasih. Walaupun seorang yang penuh kasih bebas untuk memberitahukan kesalahan-kesalahan seorang saudara secara pribadi, namun ia sangat enggan mengungkapkan di hadapan umum. Demikian kita memperlakukan kesalahan kita sendiri, dan begitu jugalah kasih mengajar kita bagaimana memperlakukan kesalahan orang lain. Kita tidak perlu mengumumkan kesalahankesalahan itu untuk mempermalukan dan mencela mereka, namun menutupinya dari perhatian masyarakat luas selama kita masih mampu melakukannya, serta tetap setia kepada Allah dan kepad orang lain.

\section{Kasih itu Percaya Segala Sesuatu}

Ia tidak pernah kehilangan iman, tidak pernah berhenti berharap, bahkan di dalam menghadapi hal-hal yang tidak diharapkan dan penderitaan. Sesunggunya kasih tidka menghancurkan kebijaksanaan sama sekali, dan membuat orang percaya begitu saja padal setiapp perkataan dengan kepolosan dan kebodohan belaka 
(Ams.14:15). Hikmat dapat tinggal bersama kasih, dan kasih akan berlaku hati-hati. Namun kasih itu sendiri suka mempercayai yang baik dari semua orang, untuk menjaga pendapat yang baik tentang orang lain ketika tidak tampak ada hal-hal yang bertentangan. Bahkan, ia tetap percaya walaupun mungkin ada sedikit ketidakjelasan, ketika bukti-bukti yang ada samar-samar. Semua kasih penuh ketulusan, cenderung mencari yang terbaik dari segala sesuatu, serta menampilkan wajah yang terbaik dari segala sesuatu itu. Kasih akan menilai segala sesuatu dengan baik dan percaya semuanya baik, sejauh memiliki alasan yang cukup. Ia lebih suka menaruh rasa percaya melampaui penampilan yang ada untuk mendukung suatu pendapat yang baik. Namun, dengan rasa enggan kasih dapat berubah menjadi sangat tidak percaya dan ia akan menjaga dirinya dengan seadil dan sejujur mungin. Dan, walaupun tidak dapat mempercayai yang baik mengenai orang itu, dan terus berharap sepanjang masih ada dasar untuk berharap. Betapa baik dan menyenangkan kasih kekristenan itu. Betapa indahnya pikiran yang telah dilarutkan di dalam kebajikan seperti ini dan telah menyebar ke seluruh pribadinya. Berbahagialah orang memiliki api sorgawi yang berkobar-kobar di dalam hatinya, yang mengalir melalui mulutnya, dan menyebarkan kehangatannya kepada semua orang yang berurusan dengannya.

\section{Kasih itu Mengharapkan Segala Sesuatu.}

Dalam Ibrani 11:1 "iman adalah dasar dari segala sesuatu yang kita harapkan", demikian pula Paulus dalam surat-suratnya memperlihatkan bahwa iman dan kasih haruslah mempunyai unsur pengharapan bila orang Kristen ingin penderitaan (Rm.5:4, 5, 8:25; 15:4; 1 Tes.1:3; 2 Tes.1:3,4.). Orang yang memiliki kasih akan selalu berpengharapan di balik gelapnya malam akan terbit matahari di pagi hari, dibalik pekatnya kabut dan derasnya hujan akan muncul pelangi, dibalik penderitaan dan dukacita akan muncul sukacita, dibalik kesakitan akan disusul kesembuhan, dibalik pertikaian akan muncul perdamaian.

Demikian halnya soal karakter seseorang, dibalik kekerasan hati seseorang suatu saat akan ada waktu hatinya menjadi lembut, di balik kejahatan hidupnya akan ada waktu dimana muncul kesadaran akan kebaikan, akan ada waktu dirinya mengalami perubahan karakter. Kasih selalu berharap seperti itu. Itulah sebabnya kasih tidak akan segera mengakhiri suatu perkara dengan keputusasaan, tetapi tetap mengharapkan perubahan dari keadaan manusia yang paling jahat, sangat cenderung untuk berharap akan apa yang diharapkan itu. Pada kasih akan selalu ada kata bisa atau mampu dan tidak ada kata terakhir untuk tidak. Bagi kasih akan selalu ada kemungkinan untuk segala sesuatu walaupun kemungkinan sesuatu itu kecil .

\section{Kasih itu Sabar Menanggung Segala Sesuatu.}

Kasih menanggung apa yang orang lain mungkin secara sengaja atau tanpa tenggang rasa lakukan untuk menyakiti orang lain, tetapi, terutama sekali kasih menanggung segala sesuatu, bahkan keadaan yang berat, sehingga orang lain dapat keuntungan (Rm. 15:1). Henry berkata kasih itu sabar menanggung segala sesuatupanta hypomenei, artinya ia akan membiarkannya berlalu dan menahan semua kesakitan tanpa memperturutkan amarah atau menyimpan dendam, bersikap sabar terhadap hasutan, tetap teguh menahan semau kesulitan, walaupun sangat terguncang. Menahan semua bentuk sakit hati dan kata-kata yang menyakitkan, dan tetap bertahan di bawah caci maki, fitnah, penjara, pengasingan, tahanan, penganiayaan, dan kematian itu sendiri, demi mereka yang menderita dan demi 


\section{PHRONESIS: JURNAL TEOLOGI DAN MISI \\ VOL. 1 NO. 1 EDISI JANUARI-JUNI 2018. ISSN. 2621-2684}

kepentingan orang lain, serta tetap bertahan dalam keteguhan ini. Perhatikanlah, betapa besar ketabahn dan keteguhan yang bisa diberikan kasih bagi pikiran. Apa yang tidak dapat ditanggung oleh seseorang yang mengasihi orang yang dikasihinya dan untuk kepentingannya! Sebanyak apa pun pengabaian dan kesakitan, ia akan menanggungnya! Seberapapun banyaknya bahaya, akan dihadapinya dan seberapa banyak pun kesulitan akan ditemuinya!.

\section{Kasih itu Tidak Berkesudahan}

Dalam bagian berikutnya Paulus menekankan keunggulan kasih yang lebih dari pada yang lainnya, bahwa lintasan dan jangkauan kasih yang tiada tara. Di dunia semuanya akan berhenti tetapi hanya kasih yang akan lekang dan bertahan sampai ke sorga. Menurut Henry, kasih adalah anugerah yang tetap ada dan tidak pernah terputus, berlangsung terus seperti kekekalan, sebaliknya karunia-karunia yang dengannya jemaat Korintus sangat menilai tinggi diri mereka dan menyombongkan diri, hanya berlangsung singkat. Karunia-karunia itu hanya diperlukan membangun iman jemaat di atas muka bumi ini, dan hanya berlangsung sementara saja, tidak terus berlanjut selama jemaat masih berada di dalam dunia ini. Namun di sorga semuanya akan digantikan, yaitu semua yang sekarang menjadi pusat dan unsur kasih. Ketika semua karunia itu tidak ada lagi, anugerah kasih itu akan di bawa sampai ke sorga, sementara yang lainnya itu tidak mendapat tempat di sana karena sudah tidak berguna lagi.

Istilah tidak berkesudahan, secara harafiah artinya tidak runtuh. Kasih yang sungguh-sungguh akan bertahan dalam ujian waktu dalam hubungan dengan manusia. Karena ia "pengikat yang mempersatukan dan menyempurnakan" (Kol.3;14); kasih adalah perekat ilahi dan tanpa itu kesatuan umat Allah akan berantakan. Kasih tidak pernah berakhir karena ia bagian dari kekekalan, ia akan bertahan jauh melebihi segala sesuatu yang mempunyai keabsahan dan kedudukan penting di dunia ini. Itulah sebabnya Paulus mengatakan bahwa kasih akan tinggal tetap apabila karunia-karunia lain telah lenyap.

Dalam bagian ini Paulus, menekankan bahwa pengetahuan dan nubuat akan berakhir artinya kemampuan kenabian akan berakhir. Akan tiba waktunya orangorang berdosa tidak lagi membutuhkan kecaman dan penghiburan dari Injil, ketika Kitab Suci tidak lagi perlu dijelaskan, ketika tidak ada lagi masa depan yang tersembunyi yang harus disingkapkan. Bahasa roh juga akan berhenti, dimana cara beribadah misterius dengan Allah ini (14:2) akan menjadi kuno ketika orang-orang kudus dapat berbicara kepada-Nya secara langsung, dan dengan bertatap muka (ay.12). Pengetahuan di masa kini yang tidak sempurna akan lenyap bila ia digantikan oleh pemahaman yang sempurna. Bahkan pengetahuan yang kita peroleh lewat pengilhaman pun hanyalah sebagian saja menggambarkan tentang Allah dan dunia rohani. Sesungguhnya, Paulus mengatakan bahwa karunia-karunia ini "akan dihancurkan oleh Allah sendiri.

Segala sesuatu akan diubah jika yang sempurna tiba. Lalu segala sesuatu yang tidak sempurna itu akan lenyap. Kesempurnaan artinya keseluruhan dibandingkan dengan yang sebagian. Henry menekankan ketika yang sempurna tiba, maka yang yang tidak sempurna itu akan lenyap. Artinya begitu tujuan telah tercapai, sudah barang tentu semua sarana yang pernah digunakan tidak diperlukan lagi. Sudah tidak diperlukan lagi adanya karunia berbahasa, bernubuat, dan pengetahuan melalui ilham, mengenai kehidupan yang akan datang, karena saat itu jemaat aka nada di 
dalam kesempurnaan. Pada saat itu Allah akan dikenal dengan jelas, di dalam gerak hati, dan sesempurna yang dapat dilakukan oleh kemampuan akal budi yang telah dimuliakan.

Kata Yunani "yang sempurna" digunakan juga untuk menunjuk pada kematangan orang dewasa (bnd.2:6 dengan 3:1; 14:20). Paulus menjelaskan proses pertumbuhan dan perkembangan manusia. Memang kehidupan ini tidak sempurna (Flp.3:12), tetapi harus ada pertumbuhan di dalam kedewasaan Kristen, seperti halnya seorang anak-anak berkembang dari kanak-kanak hingga dewasa.

Paulus menyatakan bahwa, ketika aku kanak-kanak, aku berpikir kanak-kanak; suara bunyi digantikan oleh bibir yang terbata-bata, lalu muncullah potonganpotongan kata dan frasa (kalimat), hingga seni bicara dikuasai. Ketika aku berpikir, atau bernalar-elogizomēn, seperti kanak-kanak. Tetapi ketika aku menjadi dewasa, aku meninggalkan sifat kanak-kanak itu. Seperti itulah perbedaan antara bumi dan surge. Betapa sempitnya pandangan anak-anak atas banyak hal dibandingkan dengan orang dewasa. Sudah wajar bagi manusia bahwa ketika akal budi sudah matang dan dewasa, ia akan memandang rendah dan meninggalkan pikiran-pikiran kanak-kanak mereka, membuangnya jauh-jauh, menolaknya, menganggapnya sebagai sesuatu yang tidak ada apa-apanya. Begitulah juga yang akan kita pikirkan mengenai semua karunia dan pencapaian kita yang sangat berharga di dunia ini, ketika kita akan masuk ke dalam surga.

Memang setiap orang lebih dahulu berpikir seperti kanak-kanak, dalam cara yang sederhana dan tidak rumit. Seorang dewasa terlebih dahulu memiliki sifat-sifat kanak-kanak itu, ia mempunyai persepsi yang terbatas tentang realitas, gagal melihat nilai-nilai yang sesungguhnya, tidak dapat melihat jauh daripada dunianya yang kecil. Apakah dalam hal ini, Paulus menegur orang-orang Korintus yang gagal menilai dengan nalar yang tepat akan pentingnya kasih dibandingkan dengan karuniakarunia rohani lainnya. Itulah sebabnya, dalam 1 Korintus 14:20 Paulus menganjurkan mereka agar tidak menjadi kanak-kanak di dalam pemikiran mereka, melainkan orang dewasa yang matang. Kedewasaan berarti berakhirnya masa kanakkanak, sekarang sesudah ia menjadi dewasa, ia meninggalkan sifat kanak-kanak itu.

Dalam ayat 12 dituliskan sekarang kita melihat dalam cermin suatu gambaran yang samar-samar. Arti melihat dalam cermin yaitu hanya melihat melalui permukaan datar pada sebuah pantulan. Maksudnya bahwa gambar itu tidaklah identik dengan objek yang dipantulkannya. Di sini Paulus bermaksud mengutip Bilangan 12:8; di situ Allah, yang berbicara kepada Musa, hamba-Nya, mengatakan "berhadap-hadapan Aku berbicara dengan dia, terus terang, bukan dengan teka-teki, dan ia memandang rupa Allah", dalam versi Yunaninya, frasa yang dicetak miring di atas diterjemahkan "samar-samar"; meskipun Allah berbicara seperti seorang manusia kepada sesamanya dengan Musa, bahkan nabi yang besar itu pun tidak dapat melihat Allah. Tetapi waktunya akan datang ketika kita berjumpa Dia muka dengan muka. Sekarang aku hanya mengenal dengan tidak sempurna; tetapi nanti (ketika dunia ini dan segala ketidaksempurnaannya berakhir) kita akan mengenal dengan sempurna. Di dalam hidup ini, dimana penyataan hanya memberikan pantulan dari keberadaan Allah dan kehendak-Nya yang menyelamatkan, orang Kristen mempunyai sebuah jaminan yang menghibur bahwa, meskinpun mereka tidak sepenuhnya mengerti dan mengenal Allah, mereka telah selamanya secara utuh dipahami-Nya (1 Kor. 8:2; Gal.4:9). Satu-satunya pengetahuan yang pasti adalah bahwa Allah di dalam 


\section{PHRONESIS: JURNAL TEOLOGI DAN MISI \\ VOL. 1 NO. 1 EDISI JANUARI-JUNI 2018. ISSN. 2621-2684}

kasih-Nya telah memilih kita untuk kekekalan; bahwa gembala yang baik itu mengenali domba-dombanya; itulah yang terpenting (Yoh.10:14).

\section{Hasil}

Dalam ayat 13 Paulus menjelaskan "demikianlah tinggal iman, pengharapan, dan kasih". Dalam pengertian apakah ketiganya itu tinggal? Bagi Paulus, ketiganya tinggal di dalam hidup ini sebagai kasih karunia Allah yang mempertahankan hidup Kristen; tanpa iman tidak mungkin ada penerimaan akan keselamatan, tanpa pengharapan tidak mungkin ada daya tahan yang penuh kesabaran, tanpa kasih tidak mungkin ada persekutuan di antara orang percaya. Namun, Paulus menilai diantara ketiganya "kasih yang paling besar', artinya kasihlah pengenapan iman dan pengharapan, antara iman dan pengharapan yang bekerja adalah kasih (Gal.5:6). Kasih adalah kuasa yang tinggal tetap yang mempersatukan Allah dengan manusia, dan manusia dengan manusia. Dallas Willard mengutip pemikiran Thomas Watson yang mengatakan bahwa buah sulung dari kasih adalah renungan pikiran tentang Allah. Dia yang sedang jatuh cinta, pikiran-pikirannya selalu pada objek tersebut. Dia yang mengasihi Allah digairahkan dan dibuat sangat gembira dengan perenungan tentang Allah. Mazmur 139:18 mengatakan "Apabila aku berhenti, masih saja aku bersama-sama Engkau."

Henry menjelaskan bahwa anugerah yang sejati jauh lebih unggul dari pada karunia-karunia rohani apa pun. Iman, pengharapan, dan kasih merupakan tiga karunia yang utama dan kasih yang paling utama. Kasih merupakan tuuan, dan dua anugerah yang lainnya itu hanyalah sarananya. Kasih merupakan kodrat ilahi, kebahagiaan dari jiwa, atau perhentian jiwa di dalam Allah yang penuh damai, dan kesukaan kudus dari semua yang kudus-Nya. Dan kasih itu akan berlangsung terus selamanya. Ketika iman berpusat pada pewahyuan ilahi dan mengaminkannya, sedangkan pengharapan berpegang pada kebahagiaan di masa yang akan datang dan menanti-nantikannya. Di sorga iman akan melebur di dalam penglihatan, sedangkan pengharapan melebur di dalam kenyataan, dan ketika kita sudah melihat dan menikmatinya, kita tidak perlu percaya dan berharap lagi. Tetapi kasih akan tetap ada karena itu merupakan kesempurnaan Allah sendiri.

Ketika orang-orang kudus bertemu di sorga, mereka akan tetap saling mengasihi, karena itu kodrat ilahi mereka. Dan di sana pun Allah akan tetap mengasihi mereka, karena itu juga merupakan kodrat Allah. Di sanalah orang-orang kudus mengalami kebahagiaan sejati dan terus memuliakan Allah. Demikianlah kelebihan dan kesempurnaan kasih dari pada iman dan pengharapan.

\section{Kesimpulan}

Dari penjelasan keenambelas karakteristik kasih kristiani di atas, patut kita evaluasi pemahaman kita tentang kasih, tetapi tidak hanya sebatas itu, kita pun perlu instrospeksi diri (dari dalam), ekstropeksi diri (dari luar) dan restropeksi diri (berulang-ulang) akan sifat dan sikap kasih kita kepada sesama, apakah sudah selaras dengan firman Tuhan. Bagi Tuhan, selama kita masih hidup selama itu pula kesempatan diberikan bagi kita untuk berubah dan berbuat yang terbaik bagi Tuhan 
dan sesama manusia pada umumnya dan terutama kepada saudara-saudara seiman. Amin.

\section{DAFTAR PUSTAKA}

Autrey Jarry, Surat Kiriman Penjara. Malang: Gandum Mas, 1988.

Barclay William, Pemahaman Alkitab Setiap Hari: Surat Galatia dan Efesus. Jakarta:

BPK. Gunung Mulia, 2012.

Henry Mathew, Tafsiran Matthew Henry: Surat Roma dan 1\&2 Korintus.

Surabaya:Momentum, 2015.

Lamb Jonathan, Integritas. Jakarta: Literatur Perkantas, 2008.

Morris Leon, Tyndale New Testament Commantaries 1 Corinthians. Grand Rapids, Michigan: Inter-Varsity Press, 1985.

Pfitzner V.C., Kesatuan Dalam Kepelbagaian: Tafsiran Atas Surat 1 Korintus. Jakarta: BPK. Gunung Mulia, 2000.

Willard Dallas, Renovation Of The Heart. Malang:SAAT, 2005. 